\title{
An Examination On Human Resource Management In Aligning To The Organizational Strategy
}

\author{
Colin Ting Si Xue \\ School of Computing and Technology \\ Asia Pacific University of Technology and Innovation \\ Kuala Lumpur, Malaysia. \\ colin9291@gmail.com
}

\begin{abstract}
Human Resource Management has been proved to be an important element in organizing business. Every organization should have their own strategy. A study has been carried out to evaluate that Human Resource Management strategy is aligned to the organization strategy. In this paper, I have examined on how Starbucks uses Human Resource Management strategy to manage their business.
\end{abstract}

\section{Indexing terms/Keywords}

Compensation and Benefit, Human Resource Strategies, Recruitment and Selection, Starbucks, Training and Development

\section{INTRODUCTION}

Nowadays the organizations have put more concern on the Human Resource Management (HRM). [19] said the organizations must have a proper HRM as it is important in managing, leading and motivating people to work. Besides, it also helps the organizations in achieving their goals and objectives and to gain a better competitive advantages. According to [30] and [47], HRM will influence organizational climate and organizational climate will influence job resources. [7] and [14] have agreed that Strategic Human Resources Management (SHRM) focuses on the plans and strategies of overall organizational strategies. In [44] article, it said that SHRM mainly focuses on HRM practices and strategic goals. SHRM will ensure that all actions that are related to the business goals are listed in the plan. Besides, SHRM also means aligning traditional HRM such as recruitment and selection, training and development and rewards with organization's strategy [37].

Human Resource Management can be divided into two types: Hard and Soft. According to [6] and [41], "soft" Human Resources Management focuses on treating employees as a source of competitive advantages through their performance, skills and flexibility. Besides, it also concentrates on what the employees want and need. Usually the strategic is for longterm. Soft HRM also helps to determine the ways to enhance the quality and flexibility of employees. "Hard" HRM focuses on the outputs, tasks, and commitment and organization development. It determines the importance of human resources that is used to help the organization to achieve its goals and objectives.

\section{LITERATURE REVIEW}

Human resources has a very important role in every organization that is it helps an organization to achieve their goals. Thus, every organization has invested a lot of money on human resources as it affects the organization performance. According to [1], performance has a direct effect to the organization's goal. There are many ways human resource practices to improve an organization's performance such as training and development, compensation and benefits and recruitment and selection.

\section{Recruitment and Selection}

Recruitment is an activity that is used to identify, seek and attract employees that will be used to select qualified employees. Selection process will begin after qualified employees has been recruited, that is to decide who will be chosen as employees in the organization [24]. A proper Recruitment and Selection (R\&S) is important to every organizations as it can help an organization to gain competitive advantages by choosing the most effective employees [50]. However, an improper R\&S will lead to failure of organization. According to [46], R\&S is one of the important practices in HRM and it will directly affect the organizational success. Selection is necessary in order to hire the right people, it is determined through their skills and qualification. When a right employee is hired, an organization can save money and time. Iceberg Model could be used by organization in staffing selection. According to [21], this model is important because it is able to help the organization to determine the employee's main competencies will match with the jobs. For example, in order to hire a sales people in company, it is necessary to prove the skills and knowledges that people has such as sales records and management theory. Then only to see less apparent competencies. This could be taken during interview and employee's personality traits. Based on McDonald website [31], McDonald has used Iceberg Model in their staff selection strategy. They will only choose the employees that suits their preferred style of working. They choose the employees by letting them to serve a customer with full instruction given. Besides, the employees will be given a set of questionnaire to make sure that their attributes suit the organization's preferred style of working. 
Training and Development

Most of the organizations will provide training to their employees. Different organizations will provide different types of training and development program to their employees. [43] said it is very important that an organization should plan training program carefully. The content of training program should regard to the needs of the employees. The fundamental goal of training is to help organization to achieve goals. [28] said that through these programs the employees are able to improve their skills and abilities, gain knowledge, critical thinking and solve problems. The researchers [22] agreed with Khawaja and Nadeem by saying training and development will increase the organization performance. Thus, the organization's performance will depend on employee's performance. This proves that there is a relationship between organization performance and employees' performance and training and development will bring benefit to the employees. [4] defined training as a systematic process and there is a need to examine every activity and process. [51] mentioned that the evaluation of training and development is essential. Through the evaluation, the organization is able to know whether the employees are able to apply their learning skills in their works. According to [2], Kirkpatrick model, developed by Donald Kirkpatrick in 1976 is the most acceptable and recognized model among several model that used to measure training effectiveness. This model contains four sequential steps:

Level 1: Reaction

The reaction of trainee for training is very important, that is their feeling. Some questions regarding to the learning experience of training will be asked in order to know whether the training is necessary or relevant to their works. Through this level, the organization is able to evaluate the objectives met or not. This is evaluated after a month of training.

\section{Level 2: Learning}

It is necessary to evaluate the skills and knowledges that the trainee has learned from training program [54]. The main purpose is to evaluate how much knowledges and skills they have learned, relevant content of training and the output. This is evaluated after three months of training.

\section{Level 3: Behavior}

The trainees should have learned some knowledges and skills in training program. They should apply these skills and knowledges on the job. Their job performance can be evaluated through interview. The biggest challenge in this level is the trainee may disappear since the difficulty increases. Thus, the trainee must give sufficient opportunity to allow the trainer to demonstrate the skills and knowledge.

Level 4: Result

This shows the result of training. The organization will be able to determine the tangible benefits gained from the training. The benefits bring to the organization such as increased production, increased sales, cost reduction, quality improvement, higher profit etc. According to Kirkpatrick [29], training result will directly affect the organization's expectations.

This model can help the organizations to achieve the goals and objectives. [42] said this model is perfectly fit to evaluate the training since every goals and objectives are divided among four small pieces according to each level. Effectiveness is checked throughout the level. Besides, the complex training program can be avoided. At the end of the training, the entire program has been summarized. This model will help to evaluate the employees in each level. Thus, pre training evaluation is not needed. According to [33], Pakistan International Airlines has used Kirkpatrick model to evaluate the effectiveness of training program. In level one, soft skills training will be given to the employees. An in-depth interview will be conducted. The model has proved that the soft skills training is successful. Around $70 \%$ of employees closely related to the job contents. In level two, through the interview, the organization successfully identified that the knowledge and skills of employees have been increased. Some of the employees applied their knowledge in their personal life. Besides, they also got promoted due to their efficient and effective of performance. Thus, the productivity has increased. In level three, through the training program, the employees' attitude and behavior also improved. Employees are able to provide a better solution when the passenger asks them question at airport. Due to their professional attitude, this proves the success of training. In level four, the above three levels are justified by the immediate supervisors. Based on their observation, they found that there is a great change in the behavior of employees especially their skills and knowledge. The overall productivity and efficiency are increased.

\section{Compensation and Benefits}

Employees are the key resource of an organization's success, the organization needs to offer compensation in order to remain talented and competent employees in organizations. [38] said compensation packages will affect the willingness of employees to stay in the organization. [8] did a research that appropriate compensation given will have effect on both employee and organizational performance. According to [18], they said compensation is a factor that affect employee performance. When the employees are willing to do extra roles, it brings positive affect to the organization. [23] agreed with proper compensation is able to motivate employees. Thus, organization needs to think different ways to reward employees in order to achieve specific [15].

One of the theory that can be applied here is Maslow's Hierarchy of Needs. According to [53], this theory is important and it is relevant in organizations. Without this theory, it will negatively affect not only organization's human resource, but also its culture and environment. As there are some organizations spent money on gaining customer loyalty but they have neglected to spend money on employee's motivation. It is very important to concentrate on employees' motivation. 

According to [34], they said that an organization is not able to success without motivating their employees. Based on Maslow's Hierarchy of Needs theory, there are five levels of needs to motivate an employee:

Level 1: Physiological Needs

This is the basic need of a people such as food, water, air etc. [11]. However, the Maslow organization said every employee must be provided with adequate amount of money in order to afford living expenses. Without it, it is difficult to let employees to contribute to the organization [26].

Level 2: Safety Needs

According to [36], the safety needs for employees are physical safety and working in a secure and stable environment. This enables them to work without any fear.

Level 3: Social Needs

It is about love, care and interaction with people. [20] said the employees should have a good relationship and interaction with colleagues. Every employee should be able to work in a team.

\section{Level 4: Esteem Needs}

This is about a people's self-respect, self-esteem, respect from others etc. According to [36], they said the organization should satisfy the employee's esteem needs by applying their skills and abilities on their jobs. Besides, appreciate the employee's work is important.

\section{Level 5: Self-actualization Needs}

This is about a people's self-respect, self-esteem, respect from others etc. According to [36], they said the organization should satisfy the employee's esteem needs by applying their skills and abilities on their jobs. Besides, appreciate the employee's work is important.

Kellogg Company, world's leading breakfast cereals producer, has used Maslow's hierarchy of needs to motivate their employees. The following explains how they satisfy their employees' needs in each level [27]:

- Physiological Needs - The Company offers competitive salaries, flexible benefits programme such as childcare voucher, discounted life assurance schemes.

- $\quad$ Safety Needs - The Company provides a safe and healthy working environment. Employees are allowed to work part-time and work at home in order to maintain a work-life balance.

- Social Needs - Employees are allowed to request sales information and company products. They also allowed to interact with their own team members.

- $\quad$ Esteem Needs - The Company has appreciated their employees' contribution. An appraisal is used to define how much employees contribute for the company. They also provide rewards for employees.

- Self-actualization Needs - Employees are allowed to take challenging tasks. For example, the employees have the opportunity to take ownership project.

\section{DISCUSSION}

Starbucks opens its first store in Seattle's Pike Place Market and the first Starbucks Latte is served in 1984 after Howard Schultz joined in 1982 [48]. There are more than millions people around the world walk into Starbucks to buy and enjoy the coffee. Besides, Starbucks offers an upbeat environment with soft music and friendly staff to serve customers. Starbucks has successfully become one of the most famous coffee retailer store in the world because the organization has used several types of HRM strategies. Garten [17] said that Starbucks has a strong human resource strategy with a well planning thus it has an effective management.

\section{Recruitment and Selection}

Starbucks has many different recruiting methods: Internal and External Recruiting. [45] said internal recruiting will be cost efficient. Although this method will spend more time but it supports employee satisfaction. [33] mentioned that using external recruiting method is able to bring in new skills into the organization. In Starbucks, all internal recruited employee will be given priority, which is new job will be posted for 3 days. Since the organization is still growing, they need to control the balance of recruiting the employee. Direct Applicants. It refers to the interns. Sometimes, the organization will directly hire interns if they are performing well. Tallariti, a former intern, work closely with the director. Few months later, she has been asked to submit her resume by director in order to identify whether she would be the best fit in the organization. Company Website. Starbucks has used and applied a marketing technique, that is not to recruit employee through many different websites. They used only one website that is their official website using Taleo's platform. A former recruiter said it was very successful to recruit employee through it. Social Media. Social media has become popular in these days. It was defined as "free participation that allows (communities) to get engaged and build genuine relationship(s)" [35]. Thus, it becomes a dominant way for recruitment.

According to [12], Starbucks treats every employee as vital asset since they are the main reasons for the organization's growth. Starbucks has recruited and selected employees with qualified skills and knowledges based on Iceberg Model. [52] also said Starbucks hired employees with different skills and knowledges. They hire the qualified and ideal employee, give them training session to improve skills and make sure they will have a fast development in the organization. [16] has 

described how Starbucks recruit employee. Applicant must first submit their application. As aforementioned, Starbucks will collect application through Taleo software. After the recruiters have gone through the applicants' information, they will inform applicant for interview. During the interview, questions regarding to the knowledge, personality and work ethics will be asked. Since the Starbucks' selection principle is: every employee must have good cooperation with each other, morale is important and collaboration skills must be strong [25].

\section{Training and Development}

Starbucks has provided many different types of training and development program to its employees. According to [25], at least 24 hours training such as customer service skills and work skills will be given to the new employees during their first month post. A wider range of training focusing on leadership skills and customer services will also be given. [13] describe the training and development strategy used by Starbucks:

Starbucks put lots of effort on organizing training and development program. Usually the training program is done by management, its partner and store managers. Before training begins, needs analysis is performed to ensure the goals can be met. For example, Starbucks current training program - "Barista 100 Training", is to ensure every trainee to pass a test on brewing coffee. The training includes computer-based test, internship, face-to-face interview, on-the-job coaching etc. Based on its training program partner, [10], Starbucks new training program combine "formal learning with on the job practice and individual development discussions". During the training, the trainer will provide guidance while the partner will also provide guided modules for trainees. The trainer is able to give feedback immediately and suggestions for improvements. The first part of training, Starbucks Experience, which the trainees need to know the whole experience that Starbucks provide to customers. The next part of training is Whole Bean, Brewed Coffee \& Tea and Food Case training. In this training, its partner will guide trainee on brewing coffee. Besides, the volume of recipes used to make a coffee is provided. Sixteen hours is given to trainee for bar practices. After the training, pre/post-test is conducted to evaluate the knowledge or skills learned.

\section{Compensation and Benefits}

Starbucks chairman, Schultz said by giving compensation to the employee, it will bring a higher profit and make more competitive to the organization. According to [5] they have defined a framework for employee's performance: Team work + Team trust + Recognition = Employee Performance. In [25] research, he discussed that Starbucks is an organization that always willing to invest on employees due to the understanding the feeling for people who was from poor background. Starbucks believes that the organization should put employee first and respect every contribution they have made since the employees will provide a first-class service to their customers and thus increase the profit. In Starbucks, the management has implemented a compensation plan to be given for every employee for both part time and full time employee. In his article, he mentioned that most of the organizations do not give compensation for part time employee. Starbucks has applied Maslow's Hierarchy of Needs here. In order to satisfy physiological needs, Starbucks has provided enough wages for employees to ensure they are able to afford living expenses.

Starbucks will provide different wages range for different workers however the wages do not vary much. Besides, their employees are allowed to buy the organization's stock or share with cheaper price. In order to satisfy safety needs, Starbucks will provide employee healthcare packages, health and dental insurance, employee assistance program and disability insurance. The medical insurance offering includes hospitalization, labs and x-rays, treatment etc. [39]. In order to satisfy social needs, Starbucks treat their employees with love, care and respect. [40] stated Starbucks provide a great working environment and the organization treats every employee with respect and dignity. [52] agreed with [40] by saying one of the principle in Starbucks is "treat each other with respect and dignity". Starbucks treats their employees as partners because they are one of the main resources of business success. Starbucks satisfies self-esteem needs by giving rewards to employees. According to [49] employees are able to get a wide range of perks, benefits and assistance. They will be given a $30 \%$ in-store and online discounts, a free pound of coffee and tea a. Starbucks satisfies employees' self-actualization needs by listening opinions and feedbacks from employees. Starbucks always provide chance for their employees to think creatively. According to [9], he said Starbucks CEO, Schultz always send email and make phone calls to different store locations to ask for opinions and feedbacks on products. Different employees will have different creativity.

\section{CONCLUSION}

In conclusion, this paper has examined that Starbucks' Human Resource Management strategy is aligned to the organizational strategy. There are three types of Human Resource Management strategies used by Starbucks. First one is Recruitment and Selection. The theory that they have applied is Iceberg Model. Starbucks treats their employee as their vital asset. The second one is Training and Development. The theory that they have used is Kirkpatrick's model. Starbucks offered many different types of training for their employees. Third one is Compensation and Benefits. Starbucks has used Maslow's Hierarchy of Needs model in order to satisfy every employee. It is very important to motivate employees as they will perform better in order to help organization to achieve objectives.

\section{REFERENCES}

[1]Alamdar, H. K., Muhammad, M. N., Muhammad, A. \& Wasim, H., 2012. Impact of job satisfaction on employee performance: An empirical study of autonomous Medical Institutions of Pakistan. African Journal of Business Management, 6(7), pp. 2697-2705. 
International Journal of Management and Information Technology [2]Alan, M. S. \& Lisa, A. B., 2012. An investigation into the relationship between training evaluation and the transfer of training. International Journal of Training and Development, 16(2), pp. 118-127.

[3]Alexis, N. S., Whitney, B. M., Eden, B. K. \& Michelle, R. H., 2012. The Ins and Outs of Diversity Management: The Effect of Authenticity on Outsider Perceptions and Insider Behaviors. Journal Of Applied Social Phychology, 42(1), pp. 2155.

[4]AIYahya, M. S. \& Norsiah, B. M., 2013. EVALUATION OF EFFECTIVENESS OF TRAINING AND DEVELOPMENT: The Kirkpatrick Model. Asian Journal of Business and Management Sciences, 2(11), pp. 14-24.

[5]Amena, S. \& Shahid, M. A., 2013. Power and culture of teamwork. Global Business and Economics Research Journal, 2(3), pp. 50-70.

[6]Analoui, F., 2007. Strategic Human Resource Management. Boston: International Thomson Business Press.

[7]Armstrong, M., 2006. Human Resource Management Practice. 10 ed. London: Cambridge University Press.

[8]Bilal, J. \& Naintara, S. R., 2011. Impact of Compensation, Performance Evaluation and Promotion Practices on Government Employees Performance VS Private Employees Performance. Interdisciplinary Journal of Contemporary Research in Business, 3(8), pp. 907-913.

[9]Brookmire, D., 2012. Should Leaders Communicate or Listen?. [Online] Available at: http://www.clomedia.com/2012/11/07/should-leaders-communicate-or-listen/

[Accessed 293 2016].

[10]Cafe, T. $\quad$ P., $\quad$ n.d. Starbucks. [Online] Available at: https://thepartnercafe.com/portal.jsp?Py3uQUnbK9L2RmSZs02CjV7HQ+NLQxTwl7EG9nzF38kk=C [Accessed 123 2016].

[11]Chukwudi, F. A., Odogwu, C. C. \& Adedehinbo, E. B., 2012. Motivation and Employees' Performance in the Public and Private Sectors in Nigeria. International Journal of Business Administration, 3(1), pp. 31-40.

[12]Collins, K., 2012. Human Resource Management. In: Exploring Business. Washington: Flat World Knowledge, pp. 313-314.

[13]Elizabeth, M. E. \& Andrew, K. H., 2010. Starbucks: Continual Training, s.I.: University of Portland.

[14]Esther, W. W., Elegwa, M. \& James, K., 2012. Relationship between Strategic Human Resource Management and Firm Performance of Kenya's Corporate Organizations. International Journal of Humanities and Social Science, 2(10), pp. 62-70.

[15]Falola, H. O., Ibidunni, A. S. \& Olokundun, M., 2014. Incentives Packages and Employees' Attitudes to Work: A Study Of Selected Government Parastatals In Ogun State, South-West, Nigeria. International Journal of Research in Business and Social Science, 3(1), pp. 63-74.

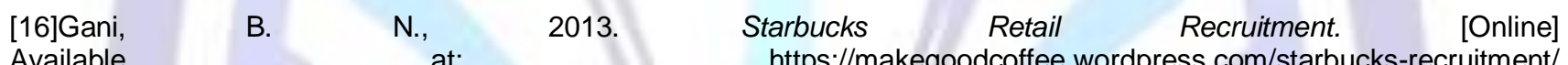

[Accessed 103 2016].

https://makegoodcoffee.wordpress.com/starbucks-recruitment/

[17]Garten, A., 2010. Case Study: An Analysis of Human Resources Practices at Starbucks Coffee Company, s.I.: s.n.

[18]Hafsa, S., Namrah, A. \& Shahzad, G., 2015. Impact of Human Resource Management Practices on Employees Performance. Middle-East Journal of Scientific Research, 23(2), pp. 329-338.

[19]Hamid, J., 2013. Strategic Human Resource Management and Performance: The Universalistic Approach - Case of Tunisia. Journal of Business Studies Quarterly, 5(2), pp. 184-201.

[20]Hashim, Z., Shehzad, A., Waqar, N. \& Muhammad, A., 2014. The Impact of the Motivation on the Employee's Performance in Beverage Industry of Pakistan. International Journal of Academic Research in Accounting, Finance and Management Sciences, 4(1), pp. 293-298.

[21]Hsieh, S. C., Lin, J. S. \& Lee, H. C., 2012. Analysis on Literature Review of Competency. International Review of Business and Economics, 2(1), pp. 25-50.

[22]lftikhar, A. \& Siraj, u. D., 2009. EVALUATING TRAINING AND DEVELOPMENT. Global Journal of Medical Sciences, 7(5), pp. 165-166.

[23]lkhlas, A. \& Mohammad, H. a.-K., 2010. Human Resource Management and Turnover Intentions in the Jordanian Hotel Sector. Research and Practice in Human Resource Management, 18(1), pp. 46-59.

[24]Jashim, U. A., Ayesha, T. \& Tashfeen, H., 2006. Human Resource Management Practices. A Case Study of the Supply Chain Department of Square Pharmaceuticals Ltd., 11(1), pp. 89-107.

[25]Jianfei, X., 2014. Analysis of Starbucks Employees Operating Philosophy. International Journal of Business and Social Science, 5(6), pp. 55-63. 
International Journal of Management and Information Technology [26]Kaur, A., 2013. Maslow's Need Hierarchy Theory: Applications and Criticisms. Global Journal of Management and Business Studies, 3(10), pp. 1061-1064.

[27]Kellogg, 2011. Building a better workplace through motivation, Washington: The Times 100.

[28]Khawaja, J. \& Nadeem, A. B., 2013. Training and Development Program and its Benefits to Employee and Organization: A Conceptual Study. European Journal of Business and Management, 5(2), pp. 243-252.

[29]Kickpatrick, D., 2008. Evaluating training programs. 3rd ed. s.I.:Tata McGraw-Hill.

[30]Maureen, D. \& Arnold, B., 2010. Psychosocial safety climate as a precursor to conducive work environments, psychological health problems, and employee engagement. Journal of Occupational and Organizational Psychology, 83(3), pp. 579-599.

[31]McDonald, 2008. Recruitment \& Training at [Online] Available at: http://www.mcdonalds.co.uk/content/dam/McDonaldsUK/People/Schools-andstudents/mcd recruitment training.pdf

[Accessed 124 2016].

[32]McIntyre, $\quad$ S., $2010 . \quad$ Employee $\quad$ Recruitment $\quad$ Methods. [Online] Available at: http://human-resources-management.suite101.com/article.cfm/employee-recruitment-methods [Accessed 123 2016].

[33]Mehwish, R., 2015. Training Evaluation in an Organization using Kirkpatrick Model: A Case Study of PIA. Journal of Entrepreneurship \& Organization Management, 4(3), pp. 1-8.

[34]Muhammad, B. A., Ejaz, W. \& Saif, U. J., 2012. Impact of Employee Motivation on Customer Satisfaction: Study of Airline Industry in Pakistan. Interdisciplinary Journal of Contemporary Research in Business, 4(6), pp. 531-539.

[35]Narvey, J., 2009. Let's Get Social: Vancouver Social Media. [Online] Available at: http://www.bcbusiness.ca/marketing-media/lets-get-social-vancouver-social-media [Accessed 123 2016].

[36]Nickson, L. A., Henry, P. G. \& Moses, K. K., 2014. A CRITICAL ANALYSIS OF HUMAN RESOURCE MANAGEMENT PRACTICES INFLUENCING PERFORMANCE IN PUBLIC UNIVERSITIES. International Journal of Economics, Commerce and Management, 2(9), pp. 1-9.

[37]Olumide, I., 2010. Strategic human resource management, small and medium sized enterprises and strategic partnership capability. Journal of Management and Marketing Research, 5(1), pp. 1-14.

[38]Omotayo, A. O., Adenika, A. A., Hezekiah, O. F. \& Princess, T. H., 2014. Compensation packages: a strategic tool for employees' performance and retention. Leonardo Journal of Sciences, 1(25), pp. 65-84.

[39]Panara, A., 2013. Interview with Starbucks Chairman Howard Schultz. [Online] Available at: https://ubir.buffalo.edu/xmlui/bitstream/handle/10477/13389/the starbucks enterprise.pdf?sequence=1 [Accessed 293 2016].

[40]Paryani, K., 2011. Product quality, service reliability and management of operations at Starbucks. INTERNATIONAL JOURNAL OF ENGINEERING, SCIENCE AND TECHNOLOGY, 3(7), pp. 1-14.

[41]Paulinus, W. I., 2014. A Review of Soft and Hard Approaches of Human Resource Management and the Success of Real Estate Development in Nigeria. Journal of Business Management and Economic Development (JBMED), 1(1), pp. 16-23.

[42]Rafiq, M., 2015. Training Evaluation in an Organization using Kirkpatrick Model: A Case Study of PIA. Entrepreneurship \& Organization Management, 4(3), pp. 1-8.

[43]Raja, A. G. K., Furqan, A. K. \& Dr. Muhammad, A. K., 2011. Impact of Training and Development on Organizaional Performance. Global Journal of Management and Business Research, 11(7), pp. 62-68.

[44]Sani, A. D., 2012. STRATEGIC HUMAN RESOURCE MANAGEMENT AND ORGANIZATIONAL PERFORMANCE IN THE NIGERIAN INSURANCE INDUSTRY: THE IMPACT OF ORGANIZATIONAL CLIMATE. Business Intelligence Journal, 5(1), pp. 8-20.

[45]Shafique, O., 2012. Recruitment in the 21st Century. Interdisciplinary Journal of Contemporary Research in Business, 4(2), pp. 887-901.

[46]Shih, H. S., Huang, L. C. \& Shyur, H. J., 2005. Recruitment and Selection Processes Through an Effective GDSS. Computers and Mathematics with Applications, pp. 1544-1558.

[47]Simon, L. A. et al., 2015. Employee engagement, human resource management practices and competitive advantage. Journal of Organizational Effectiveness: People and Performance, 2(1), pp. 7-35.
[48]Starbucks,
Available
Starbucks
Company
Timeline.
[Online]
at: 2011.

$\underline{\text { http://www.starbucks.com.my/assets/0e40b1ea48b34b82ae0a987175f1 df25.pdf }}$

[Accessed 73 2016].

2984 | P a g e 
[49]Starbucks,

Available

[Accessed 293 2016].

[50]Tabassum, A., 2011. THE PROCESS OF RECRUITMENT AND SELECTION IN A DEVELOPING COUNTRY. CASE STUDY OF A BANK IN BANGLADESH, 31(1), pp. 55-67.

[51]Topno, H., 2012. Evaluation of Training and Development: An Analysis of Various Model. IOSR Journl of Business and Management, 5(2), pp. 16-22.

[52]Ulla, P. M. et al., 2014. Managing Diverse Employees at Starbucks: Focusing on Ethics and Inclusion. International Journal of Learning \& Development, 4(3), pp. 35-50.

[53]Vivek, K. T. \& Neha, R., 2010. PERFORMANCE AND EVALUATION OF MASLOW'S HIERARCHY THEORY OF NEEDS: CURRENT ASPECT AND MODERN TRENDS. NATIONAL MONTHLY REFEREED JOURNAL OF RESEARCH IN COMMERCE \& MANAGEMENT, 2(11), pp. 80-85.

[54]Waseem, R., Liris, A., Mujtaba, A. \& Haroon, R. K., 2015. Is Training Effective? Evaluate Training Effectiveness in Call Centers. Electronic Journal of Business Ethics and Organization Studies, 20(1), pp. 4-13. 